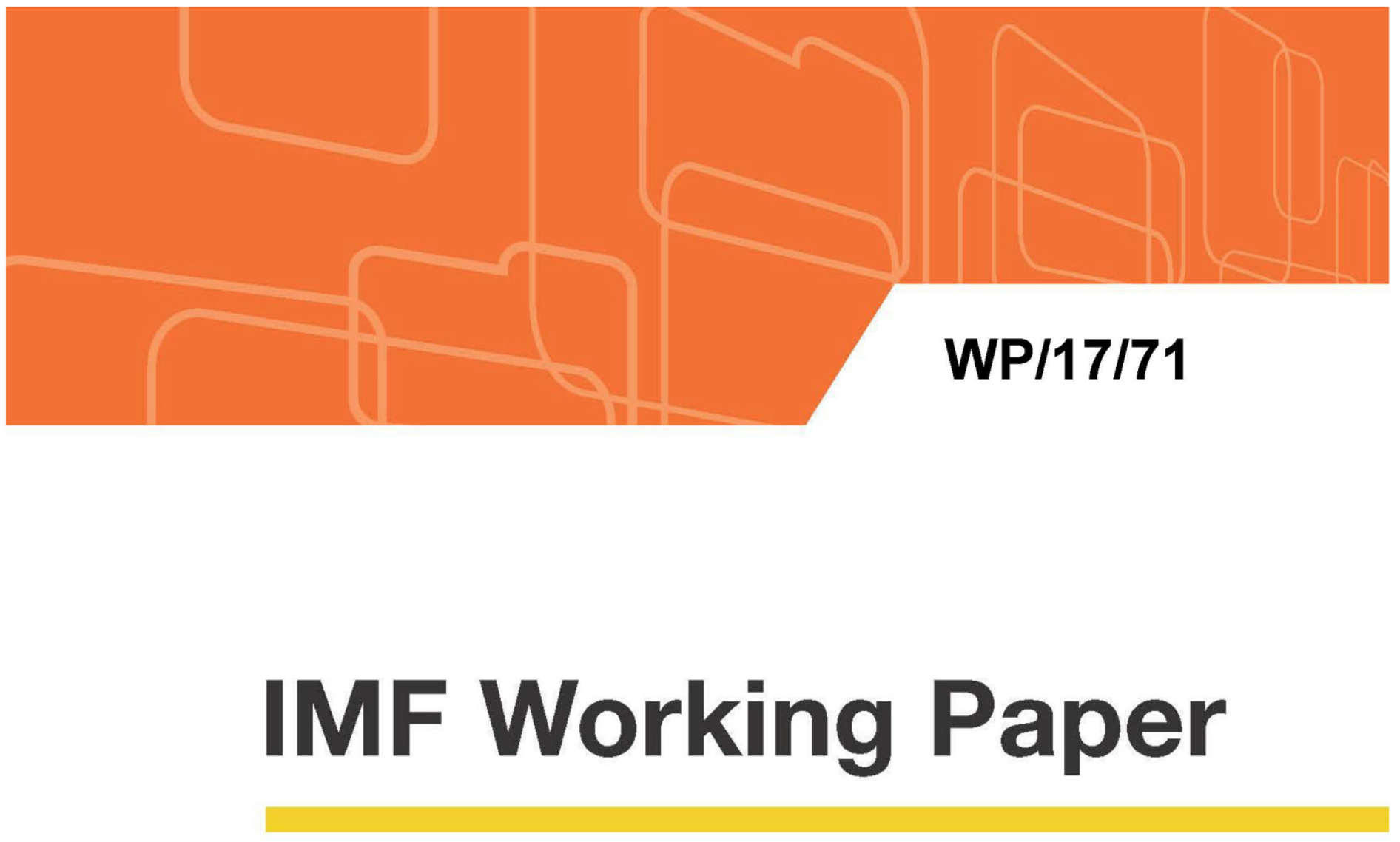

\title{
The Macroeconomics of De-Cashing
}

by Alexei Kireyev

IMF Working Papers describe research in progress by the author(s) and are published to elicit comments and to encourage debate. The views expressed in IMF Working Papers are those of the author(s) and do not necessarily represent the views of the IMF, its Executive Board, or IMF management. 


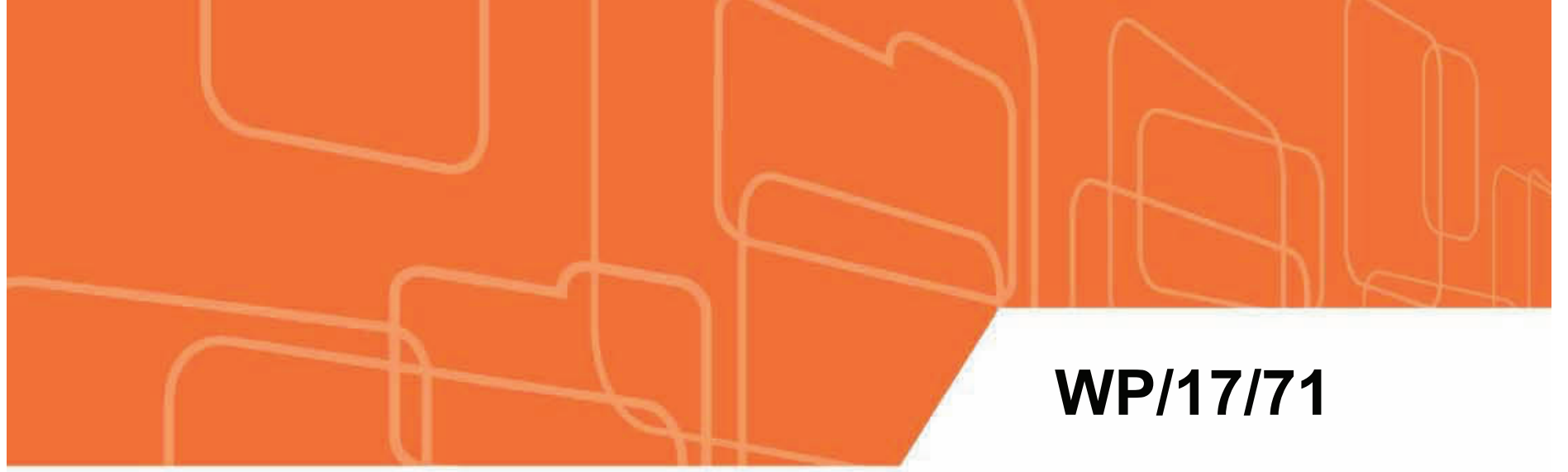

\section{IMF Working Paper}

\section{The Macroeconomics of De-Cashing}

by Alexei Kireyev

IMF Working Papers describe research in progress by the author(s) and are published to elicit comments and to encourage debate. The views expressed in IMF Working Papers are those of the author(s) and do not necessarily represent the views of the IMF, its Executive Board, or IMF management.

$$
\text { I N T ER N A T I O N A L M O N E T A R Y F U N D }
$$




\title{
IMF Working Paper
}

Middle East and Central Asia Department

The Macroeconomics of De-Cashing

Prepared by Alexei Kireyev ${ }^{1}$

Authorized for distribution by Christopher Jarvis

March 2017

\begin{abstract}
IMF Working Papers describe research in progress by the author(s) and are published to elicit comments and to encourage debate. The views expressed in IMF Working Papers are those of the author(s) and do not necessarily represent the views of the IMF, its Executive Board, or IMF management.
\end{abstract}

\begin{abstract}
The paper presents a simple framework for the analysis of the macroeconomic implications of de-cashing. Defined as replacing paper currency with convertible deposits, de-cashing would affect all key macroeconomic sectors. The overall macreconomic impact of de-cashing would depend on the balance of growth-enhancing and growth-constraining factors. Starting from a traditional saving-investment balance, the paper develops a four-sector macroeconomic framework. It is purely illustrative and is designed to provide a roadmap for a systematic evaluation of de-cashing. The framework is disaggregated into the real, fiscal, monetary, and external sectors and potential implications of de-cashing are then identified in each sector. Finally, the paper draws a balance on possible positive and negative macroeconomic implications of de-cashing, and proposes policies capable of augmenting its economic and social benefits, while reducing potential costs.
\end{abstract}

JEL Classification Numbers: E17, E40, F42, F65.

Keywords: cash, currency, demonetization.

Author's E-Mail Address: akireyev@imf.org

\footnotetext{
${ }^{1}$ The author is grateful to S.Arslanalp, J. Cartas, J. Crowley, C.Jarvis, A.Khan, D.King, D. Kostroch, G.Maciel, M. Martins, S. Matei, E.Mottu, P.Rabanal, P. van Oudheusden for careful reading and helpful comments. Any remaining errors are the author's.
} 


\section{Contents}

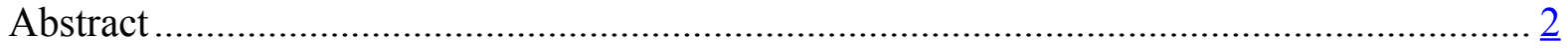

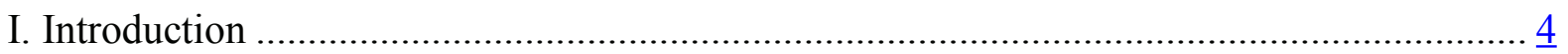

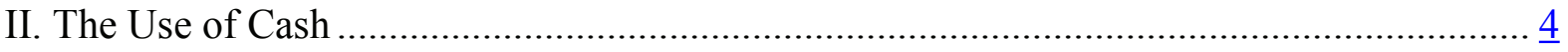

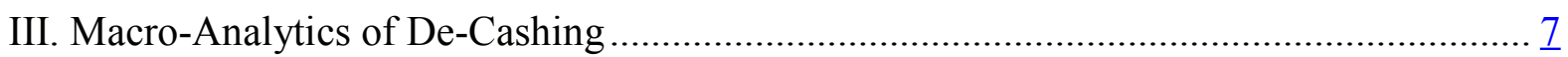

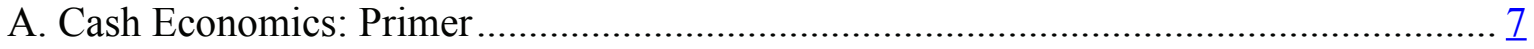

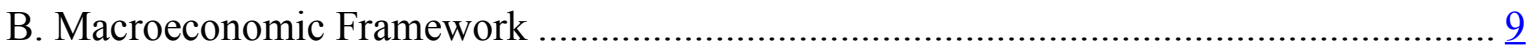

IV. Macroeconomic Effect of De-Cashing ............................................................ 13

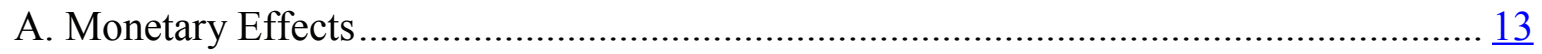

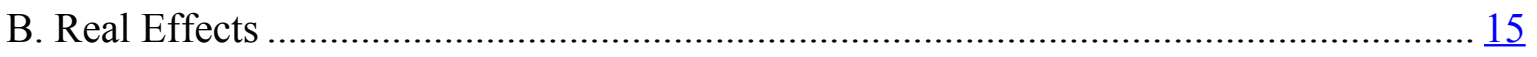

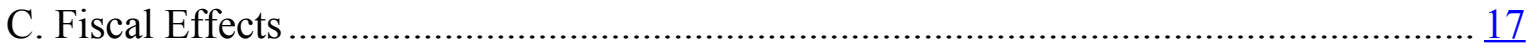

D. Balance of Payments Effects.............................................................................. 20

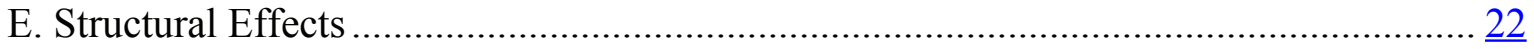

V. Conclusions and Policy Options ....................................................................... 23

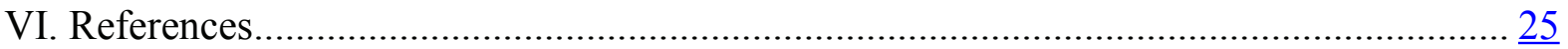

Figures

1. De-Cashing: The Macroeconomic Framework ......................................................... 11

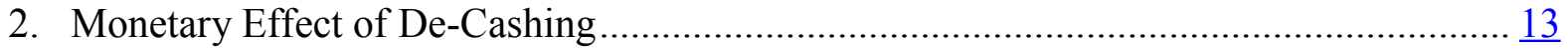

3. Real Effects of De-Cashing ............................................................................ 12

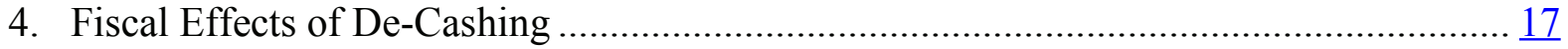

5. Balance of Payments Effects of De-Cashing ........................................................... 21 


\section{INTRODUCTION}

1. De-cashing is defined as the gradual phasing out of currency from circulation and its replacement with convertible deposits. This initiative does not in any way target the abolition of money as an institution, but is, rather, a sweeping reduction of the role of currency, its cash component, in favor of transferrable deposits, its non-cash component. The monetary authorities in many countries have already taken steps towards de-cashing. These steps include abolishing large denomination bills, imposing ceilings on cash transactions, introducing declaration requirements on the carriage of cash in and out of the country, reporting requirements for cash payments exceeding a specified amount, and even taxing cash transactions.

2. The purpose of this paper is to suggest a simple framework for the analysis of the macroeconomic implications of de-cashing. Starting from a traditional savinginvestment balance, the paper develops a four-sector macroeconomics framework, which allows for the tracing of key implications of de-cashing for any country. The macroeconomic framework is then disaggregated into the real, fiscal, monetary, and external sectors of the national economy and the rest of the world. This analytical presentation allows for the study of sector-specific implications of de-cashing and the ability to highlight possible positive and negative effects of de-cashing in the sectors of particular importance for a specific country.

3. The paper is not meant to take a view in favor of or against de-cashing in the ongoing debate. A recent and detailed overview of the positions on both sides of this heated debate is included, among others, in Sands (2016) and Rogoff (2016). The starting premise of this paper is to examine effects of de-cashing from a macroeconomic perspective. Also, the paper does not review recent money reforms (demonetization in India and some other countries). Neither does it take a view on the role of de-cashing in reducing illegally cashfinanced activities, nor on the ethical, legal and political aspects of de-cashing.

4. The rest of the paper is organized as follows. Section II briefly reviews the use of cash in the world and highlights some of the recent trends of de-cashing, including a few case studies of individual countries. Section III analyzes the statistical treatment of cash in the macroeconomics accounts, and, on this basis, proposes a traceable accounting model of decashing. Finally, Section IV includes conclusions and policy recommendations.

\section{The USE OF CASH}

\section{Cash is still used extensively across the world, in particular for small}

transactions. A study of payment habits in Australia, Austria, Canada, France, Germany, the Netherlands, and the United States has shown that in terms of the number of transactions, currency accounts for more than half everywhere, except the United States. Since the introduction of the Euro, cash in circulation has more than quadrupled in the Eurozone. In 2016, cash stood at more than $€ 1$ trillion, with both banknotes and coins still popular mediums of payment. Cash continues to play an important role in lower value transactions. 
The 2012 survey of the United States suggests that if the amount of the transaction is less than $\$ 20$, the probability that it will be settled in cash is over 90 percent. If the transaction is larger than $\$ 20$, the probability decreases to 57 percent (Bundesbank, 2014).

6. Cash remains popular for technical and symbolic reasons. Technically, cash is seen as a simple, safe, and private medium of payment. Cash helps control spending and plan a budget. Cash can be used to pay anonymously and directly without any sophisticated technical infrastructure, even without electricity, and is largely seen as irreplaceable in emergency situations. Cash has been created as the historically most convenient from of money, and carrying cash in the wallet is often perceived as a fundamental human right. On the international scale, common money has often been seen as the most discernable sign of integration, in particular in the Eurozone or CFA zones in Africa.

7. The use of cash differs substantially depending on the denomination. Low denomination banknotes are used mainly for small daily transactions, whereas high denomination banknotes represent the bulk of currency in circulation, but are not generally used for cash transactions. High denomination banknotes, although dominate the cash turnover, mainly perform the monetary function of the store of value. Such banknotes (US\$ 50 to US\$100 in the United States, $€ 50$ to 500 in the Eurozone, $¥ 5,000$ to 10,000 in Japan, and $\mathrm{Kr} 500$ to 1,000 in Sweden) represent 80-90 percent of currency in circulation, though are rarely used in daily cash payments. For daily transactions, small denomination banknotes are the most common means of payment.

8. Large denomination banknotes pose institutional risks. First, they are an important vehicle for money laundering. The larger value of the banknote makes it easier to transport larger amounts of money. As an example, US \$1 million in currency in \$100 bills weighs 22 pounds, where as one million dollars in $€ 500$ notes would weigh less than 3 pounds. Second, large denomination banknotes are more often forged. The U.S. Treasury considered re-issuing a US\$500 banknote when the Euro 500 banknotes began circulating. However, after the recognition that such a banknote would fuel worldwide criminals, it was decided not to pursue this option. Third, high denomination banknotes are most likely used for overseas circulation with no supervision from the respective central bank. One estimate for the United States suggests that about 65 percent ( $\$ 580$ billion) of all banknotes are in circulation outside of the U.S. There are a number of countries which are officially dollarized, which could in part explain this high percentage.

9. Cashless transactions have also gained importance across the world. The Federal Reserve estimates that in 2016 cashless transactions amounted to US $\$ 617$ bn, up from US $\$ 60$ bn in 2010. In Germany, 33 percent of consumer transactions are cashless. Sweden is fast becoming an almost entirely cashless society. In 2015, cash transactions made up barely 2 percent of the value of all payments made in Sweden and may drop to 0.5 percent by 2020 . In shops, cash is now used for barely 20 percent of transactions, half the number from five years ago, and way below the global average of 75 percent (Riksbank, 2016). A similar trend 
towards de-cashing is clearly observed in Norway, Denmark, and Finland.

\section{The authorities of many countries have already taken the initial steps to limit}

cash in transactions. First, some decided to abolish large denomination bills. In 2016, the ECB took the decision to abolish the $€ 500$ banknote, mainly out of concern for counterfeiting and money laundering. In other countries, some high denomination notes have been eliminated in recent years, such as Canada's \$1,000 note in 2000, and Singapore's \$10,000 note in 2014 (Sands, 2016). In Sweden, all older banknotes and coins, except the 10-krona coin, will become invalid by end-2017, and some of the banknotes and coins will not be replaced by new ones. Calls to scrap the U.S. $\$ 100$ bill - the most widely used currency note in the world-have been heard in the United States (Summers, 2016). Second, the authorities in some countries have introduced restrictions on cash payments. Restrictions on cash payments are currently in place in 12 of the $28 \mathrm{EU}$ member states (Bundesbank, 2016). In the Eurozone, an idea of imposing a ceiling of $€ 5,000$ on cash payments has been discussed. Restrictions were also put on the use of cash for specific purposes, such as paying rent (Sands, 2016). In Israel, a special committee recommended a three-phase plan to restrict the use of cash, limit the use of checks as a means of payment and exchange for cash, and promote the use of electronic means of payment. Any violation of these limits would be a criminal offense (Alony, 2014). Third, the reporting and declaration requirement on carrying cash has been in place in many countries. For example, in the United States, it is contrary to Title 26 of the U.S. Tax Code to carry more than US \$10,000 into the country without reporting it. A similar requirement is now in place for the $\mathrm{EU}$, as all sums exceeding $€ 10,000$ in cash must be declared to the customs authorities.

11. The private sector also seems to prefer to do away with cash. Many businesses in the Eurozone have self-imposed the policy of not accepting large denomination bills for payments, in particular Euro 500 and 200 bills, out of fear of counterfeit money. In the United States, getting change from a $\$ 100$ bill may pose a problem at a small business. In Sweden, banks no longer accept or dispense cash, about 900 of Sweden's 1,600 bank branches no longer keep cash on hand or take cash deposits, and many, especially in rural areas, no longer have ATMs. Swedish buses have not taken cash for years, it is impossible to buy a metro ticket with cash, retailers are legally entitled to refuse coins and notes, and street vendors-and even churches-increasingly prefer card or phone payments (Henley, 2016). 


\section{Macro-Analytics OF De-Cashing}

\section{A. Cash Economics: Primer ${ }^{2}$}

12. In monetary statistics, cash is synonymous to currency. In the strict sense, currency refers to notes and coins, which are financial instruments of fixed nominal values issued or authorized by central banks or governments (MFSM, 2016). Domestic currency is given the status of a legal tender by the constitution or other relevant law, which generally requires its mandatory acceptance in the country. The value and credibility of a currency depend on the ability of the state to support it. ${ }^{3}$ Currency in circulation is the amount of currency outside the central bank held by all residents and non-residents.

13. Currency is part of money. Money is a broader concept than currency. In addition to notes and coins, money also includes certain types of assets or instruments that are readily convertible into such banknotes and coins, for example, transferrable deposits and short-term deposits. Money is issued generally by central banks. The issuance of money can take the forms of increasing the commercial bank's deposits at the central bank or transporting of currency to the vaults of commercial banks. Transferrable deposits have characteristics similar to currency. Transferrable deposits are exchangeable for currency on demand at par, without penalty or restriction, and directly usable for making payments to third parties by check, draft, giro order, direct debit/credit, or other direct payment facility.

\section{Both currency and transferrable deposits are part of broad money and, as any} money, has four basic functions. Currency is i) a medium of exchange - a means for acquiring non-financial assets (goods, merchandises, equipment, etc.), services, and financial assets without resorting to bartering; ii) a store of value - a means of holding wealth; iii) a unit of account - a standard for denominating the prices of goods and services, and the values of financial instruments and non-financial assets, thereby providing a means for comparisons of values and for preparation of financial accounts; and iv) a standard of deferred paymenta means for settling liabilities.

15. The amount of currency placed into circulation relative to deposits is determined by demand for currency. Currency demand is determined by the bank's clients, who establish the amount they would like to have in the form of deposits and cash. The central bank places currency into circulation when it transports it to a commercial bank. ${ }^{4}$ To account

\footnotetext{
2 The discussion is based on definitions and concepts from the new MFSM 2016.

${ }^{3}$ This is not the case in all countries. For instance, the Indian Rupee is legal tender in Nepal and Bhutan, in addition to its own domestic currency.

${ }^{4}$ Transportation is not always the point where hash becomes currency in circulation. Some countries (e.g., in the Eurozone with the "Notes Held to Order" (NHTO) practice, and some Commonwealth countries with the practice of "currency chests") have arrangements with commercial banks where non-circulated 'banknotes' (i.e., paper) are transported from the central bank to vaults of commercial banks. These (partitioned) vaults are
}

(continued...) 
for this transaction in its balance sheet, the central bank reduces the 'transferable deposits' of the commercial bank and increases 'currency in circulation.' The commercial bank in its balance sheet increases 'domestic currency' and decreases its 'transferable deposits' at the central bank. However, as long as this currency stays in the vaults of the commercial bank, it does not perform the role of money. Currency only starts performing this role and is included in broad money when the bank's clients exchange their deposits for currency. Upon demand from its clients for cash, the bank reduces its currency in vault cash in exchange for a reduction in their transferable deposits. As an accounting entry, this currency in circulation is labeled 'currency outside banks' and is included in broad money liabilities.

\section{Electronic money is a special case of transferrable deposits and is classified as}

deposits rather than currency. All types of electronic money issued by residents that can be used for direct payments to third parties are included in broad money as transferable deposits. Electronic money is a payment instrument whereby monetary value is electronically stored either on a physical device or remotely at a server. To qualify as electronic money, the payment instrument must be usable for making payments to third parties. While currency has only physical security features, electronic money uses cryptography to authenticate transactions and to protect the confidentiality and the integrity of the data processing. Examples of electronic money include an electronic purse where monetary values are stored on cards for small payments; prepaid cards, except those designed for specific needs and that can be used only in a limited way; web-based electronic money, such as PayPal; and mobile money accessible on a mobile phone (eg., M-Pesa in Kenya and Tanzania). Not all electronic payments involve electronic money. For instance, credit cards or debit cards are not electronic money because no monetary value is stored on them, and neither are store cards because they are similar to credit cards, but with use limited to only the issuing stores. Internet-based currency, such as Bitcoins, is not electronic money because it does not meet the definition of currency. Bitcoin is not issued by a central bank and is not widely accepted as a medium of exchange.

\section{Therefore, currency and transferable deposits are very similar and both meet} the definition of broad money. They both can be used as a medium of exchange. They are immediately exchangeable on demand at par to acquire financial or non-financial assets. Both can be considered legal tender if the legal framework (likely the Central Bank act) indicates that. Currency is accepted for domestic transactions because of its status as legal tender. Transferable deposits are accepted for transactions because recipients perceive them as a medium of exchange. Both currency and transferrable deposits have fixed nominal (face) value. The nominal values of currency and non-interest-bearing transferable deposits are fixed, with real values changing with movements in the price level. Both currency and

physically in commercial banks, and maintained but them, but are to be seen as extensions of the central bank's vault. 'Notes' being transported to those commercial banks are still listed as assets on the central bank's balance sheet, and will only turn into a liability / banknotes when transferred out of this vault. Transportation is therefore not always the point where paper becomes currency in circulation. 
transferable deposits are transferrable as they can be used to make direct payments to a third party, and both have no or very low transaction costs. Payment by currency has no fees or other transaction costs, and the use of transferable deposits usually bears very small fees. Both currency and transferable deposits are divisible financial assets and are suitable for making small transactions. Both currency and transferable deposits do not have maturity and are immediately accessible by their holders. Finally, currency and transferable deposits earn no or low interest. Their usefulness as a medium of exchange compensates the holder for the forgone interest that could have been received by holding other types of financial assets. There is no surprise, therefore, that central banks stand ready to convert transferrable deposits into currency in unlimited amounts.

\section{The differences between currency and transferrable deposits are also}

remarkable. They are often used by both sides of the debate on the pros and cons of decashing. First, currency can become technically obsolete. Banknotes fade and break, and the efforts to remedy the problem with plastics is of little help and involve unneeded costs. Transferrable deposits do not have this problem. Second, payments with currency are anonymous, which makes them a popular vehicle for abuse, tax avoidance, terrorism financing, and money laundering. Transferrable deposits are personified and generally cannot be used for these purposes. Third, currency is prone to counterfeiting, at times on a large scale. Transferrable deposits are not. Fourth, currency is often perceived as a means to preserve privacy, i.e., economic operators generally are not interested in the history of the currency of their transaction. Also, the individual right for privacy is usually enshrined in laws and transferrable deposits store each step of the payment history, which can be viewed as a threat to privacy. Transferrable deposits lead to full transparency, at least to the issuing bank, and a complete record of transactions, which in virtue of law can be used by tax and law enforcement authorities.

\section{B. Macroeconomic Framework}

19. One way to look at the macroeconomic implications of de-cashing is through the prism of the System of National Accounts (SNA). The SNA provides an internationally recognized accounting framework, which allows for the compiling and presenting of macroeconomic data in a consistent manner (SNA, 2008). Economic agents in any economy can be subdivided into five sectors: households, enterprises, financial intermediaries, the government, and the rest of the world. All of them are linked by accounting identities. In a simplified form, these linkages can be presented as follows (Figure 1).

20. In any economy, there is supply of resources and demand for resources or their use. Supply of resources consists of its own output $Y$ and imports $I M$. These resources are used for public and private consumption $C$, investment $I$, and exports $X$ (1). According to the expenditure approach, income generated by the output is equal to the sum of its final uses (2). Additional income for the country includes net factor income and net transfers, which can be added to both sides of the identity, but are omitted here to simplify the presentation. Income 
not consumed equals saving $S$, and the difference between exports and imports equals the current account $C A$ in the balance of payments (3). Therefore, ex post, the gap between saving and investment is equivalent to the current account balance (4). In other words, the current account deficit is driven by investment exceeding saving and should be financed from abroad. The current account surplus reflects saving exceeding investment and can be used to finance investment abroad. The saving-investment balance, which is equal to the current account, is the fundamental identity of international macroeconomics.

\section{The outcome of the saving and investment balance depends on the performance} of the public and private sectors. On the left-hand side of the saving-investment balance, national saving can be presented as a sum of government saving $S g$ and private saving $S p$, and national investment as a sum of government investment $I g$ and private investment $I p(5)$. On the right-hand side of the saving-investment balance, the current account itself is part of the balance of payments identity. It says that the current account balance $C A$ plus the financial account balance $F A{ }^{5}$ should equal the change in international reserves $R$ of the country (6). In other words, any disequilibrium between saving and investment either in the public or private sector would be reflected in the flows in the financial account or reserves. Assume for simplicity that the private sector always adjusts to the equilibrium, its savinginvestment balance is zero, i.e., $S p-I p=0$, and the saving-investment balance of the government sector is the only determinant of the current account.

\section{The saving-investment balance of the public sector broadly reflects the} government's budget position. The level of government saving $S g$ depends on the fiscal balance $B$, which is the difference between revenue $\operatorname{Rev}$ and expenses $\operatorname{Exp}$, and is financed$F$ either from external sources Ext or domestic sources $D m(7)$. Revenue consists of tax revenue $T x$, non-tax revenue $N T x$, and grants grnts. Expenses include only final consumption expenditure by the general government, i.e., usually payments of wages and salaries $W \& S$, procurements of goods and services $G \& S$, and subsidies $S b$. In turn, tax revenue consists of domestic taxes $T d$ and taxes on international trade and transactions $T i$ (8). Non-tax revenue includes fees and charges $F S$ and other revenue Oth (9).

\footnotetext{
${ }^{5}$ FA refers to "net capital and financial account excluding reserve assets" and NFA refers to "net foreign assets excluding reserve assets".
} 


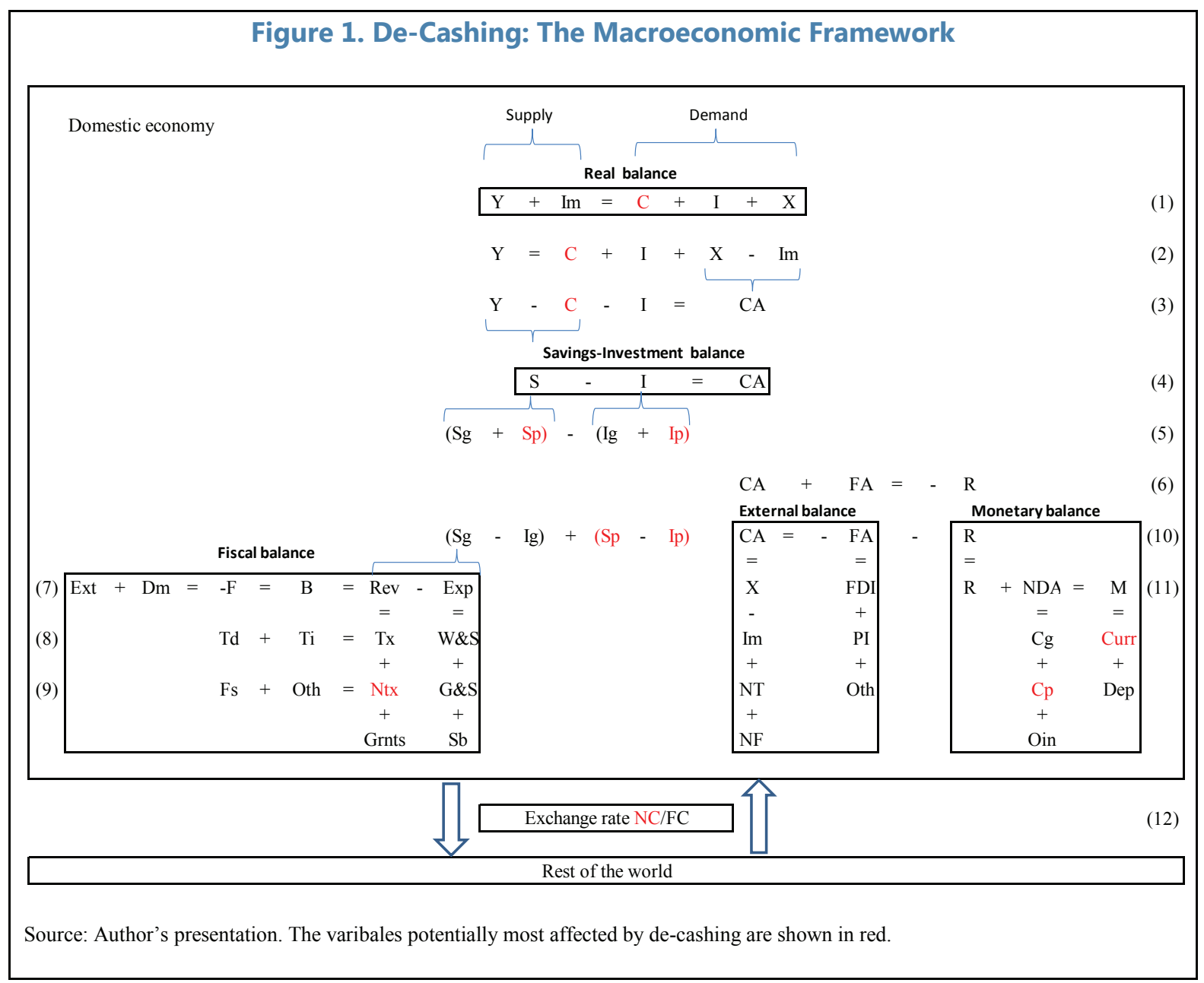

23. The current account is a crucial component of the balance of payments and the external balance. Depending on the balance between domestic saving and investment, the current account can be in deficit or surplus. In the case of a deficit, it is financed by inflows in the financial account $F A$ and/or drawing down international reserves $R$ (10). This is a budget constraint for the economy, because the deficit can persist only as long as financial inflows are maintained and the reserve level remains appropriate. In a current account surplus, the country finances the rest of the world by outflows in the financial account and/or accumulates reserves. The current account balance is usually determined mainly by the balance on trade in goods and services $X-I m$. In addition, the net factor income $N F$ and net transfers NT may be important for the current account in certain countries. The flows in the financial account can be $F D I$, portfolio investment $P I$, and other flows $O t h$, which consist mainly of public and private loans.

24. The saving-investment balance has an important impact on monetary accounts. Assuming international reserves equal net foreign assets $(N F A)$ of the central bank and no changes in the NFA of commercial banks, then change in reserves $R$ generated by the balance of payments outcome together with the changes in net domestic assets NDA lead to 
changes in broad money $M(11)$. Changes in the $N D A$ can be driven by net credit to the government $C g$, credit to the private sector $C p$, and other items net $O I N$. The monetary sector identity shows the distinction between money of external origin ( $N F A$, reserves) and domestic origin ( $N D A$, domestic credit). Unless sterilized, any accumulation of international reserves would translate into an increase in the supply of broad money for a given level of domestic credit. Because in equilibrium money supply always equals money demand, rapid accumulation of reserves may lead to a spike in inflation. Conversely, any expansion in domestic credit at a given level of reserves can have similar consequences.

\section{Finally, the saving-investment balance of any country is closely linked to the} level of the exchange rate of its currency. The exchange rate level broadly reflects the balance between supply and demand for currency between residents of the domestic economy and the rest of the world. This balance of supply and demand for currency may be an outcome of current account transactions, as exporters sell their foreign currency earnings and importers buy foreign currency to pay for imports; financial account transactions, as residents demand foreign currency to invest abroad and non-residents need local currency to invest domestically; and transactions with international reserves, as the central bank buys and sells foreign currency to achieve its policy objectives. As a result, flows under all three key accounts of the balance of payments - the current account, the financial account, and the international reserves account - have an impact on the level of the exchange rate (12).

26. How does de-cashing enter into this simple framework? On a purely macroaccounting level, commitments taken by countries in the process of de-cashing directly affect their saving-investment balance. The impulse may originate in any of the four sectors from the variables shown in red on Figure 1. In the real sector, de-cashing would directly influence private consumption and private investment, generally by shifting the means of payments from paper currency to electronic means. In the fiscal sector, the impact of de-cashing would be felt on both the revenue and the expenditure sides. On the revenue side, the level of nontax revenue for governments from seingiorage will be inevitably affected. The impact on the expenditure side will be mainly through reduced and even eliminated currency printing and transaction costs. In the external sector, the impulse should be expected from the savinginvestment balance in the private sector, where the interplay between the changes in the two components - investment and saving -- would affect the current account. Finally, in the monetary sector, the impact of de-cashing on the assets side would be from the credit to the private sector, most, if not all of which, will have to be de-cashed. On the liabilities side, the composition between currency and deposits in reserve money would change in favor of the latter. Let's look at each of these macro effects in more details. 


\section{MaCRoeconomic EFFECT OF DE-CASHING}

\section{A. Monetary Effects}

\section{The initial macroeconomic impulse of de-cashing would originate from a drop in} demand for currency. In equilibrium, the central bank stands ready to meet demand for money, be it in the form of currency or transferrable deposit, and stands ready to convert currency into transferrable deposits and transferrable deposits into currency in unlimited amounts. In fact, if demand for currency drops and is offset in full by an increase in demand for transferrable deposits, the impact on money supply will be zero (Figure 2). The process of de-cashing would be reflected on the liabilities side of the central bank balance sheet and monetary survey as a simple rebalancing between currency and transferrable deposits. On the assets side showing the sources of money supply, the net foreign assets will not be affected as this is money of external origin. Some rebalancing is possible between net claims of government and claims of the private sector, depending on their relative demand for currency and deposits. In a most probable scenario of creating incentives for de-cashing, the public sector most likely would reduce its demand for currency more than the private sector, for example, if a decision is taken to pay all public sector salaries by cashless means, i.e., by their transfer to deposits of public employees, and to pay taxes only with cashless means. The private sector may also react to incentives for de-cashing if the authorities introduce a requirement that all payments exceeding a certain amount should be made by cashless means. In any case, the rebalancing in monetary accounts would be purely mechanical with no impact on money supply.

Figure 2. Monetary Effect of De-Cashing

Monetary survey

\begin{tabular}{|c|c|c|c|}
\hline Assets/Counterparts & Impact & Liabilities & Impact \\
\hline Net foreign assets & 0 & Broad money & 0 \\
\hline Central bank & 0 & Currency outside depository corporations & - \\
\hline Commercial banks & 0 & Transferrable deposits & + \\
\hline Net domestic assets & 0 & Other deposit included in broad money & 0 \\
\hline Net claims on government & $+/-$ & Debt securities included in broad money & 0 \\
\hline Claims on other resident sectors & $+/-$ & & \\
\hline Other items net & 0 & & \\
\hline
\end{tabular}

\begin{tabular}{|l|c|c|c|}
\hline \multicolumn{1}{|c|}{ Assets/Counterparts } & Impact \\
\hline Net foreign assets of the central bank & 0 \\
Net domestic assets & 0 \\
Net claims on government & $+/-$ \\
Claims on other depositary corporations & $+/-$ & Lonetary base & Impact \\
Other items net & 0 & Currency in circulation & 0 \\
Transferrable deposits & - \\
Other deposits & + \\
Debt securities issues by central banks & 0 \\
\hline
\end{tabular}

Source: Author's presentation based on the Monetary and Financial Statistics Manual (MFSM, 2016). 
28. Therefore, the de-cashing incentives should be explicitly included in the demand for currency estimations. Demand for currency is usually modeled in an error correction framework to account for a possible cointegration between currency holdings, GDP, and interest rates. Indicators of ease of access to currency, such as the number of ATMs, fund transfer terminals, and bank branches per capita, and the ratio of self-employment to total employment in the long-run relationship can be also included. Additional variables to capture the impact of de-cashing on currency demand may include the projected share of salaries paid in cash, an implicit opportunity cost of holding cash, and the number of checking and other transferrable accounts held by economic agents.

\section{De-cashing may help improve the transmission mechanism of monetary policy.} In principle, the transmission of monetary impulses from the policy rate to inflation may become easier as all rates - money market, interbank, bank deposit, and lending - may react faster to the changes in the policy rate as economic agents would have fewer non-interest bearing assets in the form of saved currency. In particular, the negative interest rate policy becomes a feasible option for monetary policy if savings in physical currency are discouraged and substantially reduced. With de-cashing, most money would be stored in the banking system, and, therefore, would be easily affected by negative rates, which could encourage consumer spending. Moreover, currency has not been an efficient instrument of monetary policy, as in most countries currency is neither the largest part of money supply, nor an efficient mechanism for providing liquidity. The amount of currency in circulation has no impact on inflation, and there are no quantitative limits on banknote issuance in central banks, which also suggests that currency has largely lost its role in monetary policy, in particular in developed countries. The opposite scenario is also possible, in particular in developing countries with a large share of currency in money, where currency may have an impact on inflation. Even a small negative interest rate would likely result in a sudden jump in demand for cash, both during and after the period of negative interest rates. The supply of cash would increase to meet this demand. In this scenario, negative interest rate policies might be feasible only if cash and prepaid debit cards were eliminated, but even then they would be highly controversial. Also, with negative interest rates, agents could move into other assets for storing value if domestic interest rates are largely negative (think of using other countries' paper currencies, virtual currencies, gold, real estate, etc.).

\section{After de-cashing, the banking system laden with fresh deposits would be able to}

boost lending. In countries where the depositor base is weak, de-cashing would help increase deposits as economic agents convert their currency holdings into convertible and other types of deposits with the banking system. Availability of deposits should in principle help reduce the lending interest rate and make credit more affordable, therefore increasing borrowing and contributing to growth. Clearly, de-cashing is not the only instrument to lower the interest rates. Central banks can lower interest rates whenever they consider it desirable, as long as the zero lower bound is not binding. And ever when the zero bound is binding, banks would have excess liquidity. Banks' credit is also constrained by capital requirements and sound 
lending considerations.

31. The only useful function of currency, which can be lost with de-cashing, is that demand for cash may help predict financial crises. Such crises usually happen when the general public loses confidence in banks and bank money and run into hard cash erroneously viewed as a safe haven. The strong demand for cash in September 2008 reflected the panic that swept across most developed countries with the visible onset of one of the biggest crises in history. The rise in demand for currency, in particular for high denomination banknotes, was mainly due to an increase in precautionary holdings by people concerned about the liquidity or solvency of financial institutions, and by financial institutions as a contingency. However, it is not entirely clear whether de-cashing would eliminate the ability to see early warning signs. Even in a fully cashless society, people may revert to gold, other commodities, or other (still existing) cash currencies (such as USD), demand for which would function as early earning indicators.

\section{Finally, de-cashing may have implications for central bank independence,}

mainly in emerging economics. It may be argued that de-cashing would lead to a loss of the revenue from seingiorage, one of the important sources of revenue for central banks that allow them to maintain financial independence. However, for most central banks seingiorage is not a significant revenue stream and at times even notional, as all of it is transferred to the general budget. For example, in the euro area, the ECB receives interest only on its 8 percent share of the total currency issuance, as national central banks members of the Euro system put most currency into circulation. Seigniorage from high denomination banknotes does not exceed 0.1 percent of GDP in the USA, the Eurozone, Japan, the UK, and Switzerland (Sands, 2016). The ECB earns interest only on its share of the issued currency and at a very low marginal rate (or fixed rate) for the Euro system's main refinancing operations. Moreover, most central banks have diversified revenue sources. In addition to the seingiorage, they earn income on their holdings of foreign reserves, which are usually invested in interest bearing assets, holdings of government securities, issuances of their own securities, revaluation of assets with rising prices, including gold, exchange rate differentials, and other sources. Also, most central bank laws have arrangements for limited profit distribution arrangements with their sovereigns, in particular to safeguard financial independence. Therefore, the examples listed are not necessarily the countries that face significant threats to central bank independence. It is, however, in particular central banks in numerous emerging markets where seigniorage is key for the central bank's financial independence. Obviously, central banks also bear costs, but their substantial part, such as printing, minting, and retiring banknotes and coins, would be dramatically reduced, if not eliminated, with de-cashing.

\section{B. Real Effects}

33. De-cashing would have an impact on growth, which may be both positive and negative. The positive impact in the form of higher growth can be expected as de-cashing 
would reduce transaction costs in the economy estimated at about 2-2.5 percent of GDP (Bundesbank, 2014). Lower costs would mean higher profits, investment, and ultimately growth. This positive impact may be significant as cash transactions are mostly conducted with small denomination bills and are thus the cost of such multiple small transactions may be substantial. Second, de-cashing may reduce the underground and grey economy, and, therefore, increase the GDP captured by official statistics beyond the usual estimates of the underground economy already included in GDP calculations, thus making them explicitly contribute to GDP. On the other hand, de-cashing may have negative repercussions for private sector growth as a substantial part of private investment (house construction, remodeling, and extensions), especially those financed by remittances, is settled in cash. Decashing may introduce disruptions in this well-established process. Also, with the elimination of high denomination banknotes, consumers will have to use an increasing number of lower denomination banknotes to settle the same transaction, which will increase costs. Finally, should governments impose de-cashing without the general approval of the population, decashing may lead to social tensions, mistrust, walkouts, demonstrations, and, as a result, GDP losses.

34. At a more granular level, the GDP is produced and spent, and currency is used as a medium of exchange in this process. On the supply side, GDP can be further decomposed into the value added plus the adjustment of taxes less subsidies on products in the primary sector (mining and agriculture), secondary sector (manufacturing), and tertiary sector (services) (Figure 3), and can explicitly show the public and private sectors, both on the supply and demand sides. Arguably, the use of cash is substantially higher in the private sector than in the public sector. Depending on the shares of private and public ownership, the impact may be felt mainly in the tertiary sector, where most services are provided by private agents, and the secondary sector, if the role of the private sector is high in a particular economy. As natural resources are usually in the public sector, the impact of de-cashing on it may be marginal.

\section{On the demand side, de-cashing would affect both private consumption and}

private investment. While public consumption and investment are usually non-cash transactions, private consumption is strongly influenced by the amount of net disposable income. People generally spend and consume more from their disposable income if they feel financially safe, therefore increasing demand for currency. As consumption spending by the private sector is an important GDP component and is conducted in a significant part in paper currency, de-cashing may have a negative impact on it and somewhat hamper economic growth. Investment, however, should be generally a lesser source for currency demand, in particular in developed countries where it is executed in bank money. Therefore, de-cashing most likely will not significantly affect public consumption and investment, but may create temporary hurdles for private consumption and investment. 


\begin{tabular}{|c|c|c|c|}
\hline \multicolumn{4}{|c|}{ Figure 3. Real Effects of De-Cashing } \\
\hline Supply & Impact & Demand & Impact \\
\hline GDP (public and private) & $+/-$ & GDP (public and private) & $+/-$ \\
\hline Primary sector & - & Gross domestic expenditure & $+/--$ \\
\hline Secondary sector & $+/-$ & Consumption & $+/--$ \\
\hline Tertiary sector & + & Public & 0 \\
\hline Public administration & 0 & Private & + \\
\hline & & Gross fixed capital formation & $+/-$ \\
\hline & & Public & 0 \\
\hline & & Private & \\
\hline & & Change in stocks & \\
\hline & & Resource gap & + \\
\hline & & Exports of G\&NFS & + \\
\hline & & Imports of G\&NFS & + \\
\hline
\end{tabular}

\section{Fiscal Effects}

36. De-cashing will have an impact on the fiscal balance of the de-cashing country. As shown above, the fiscal balance is directly linked to the saving-investment balance of the public sector, and, therefore, can have a major impact on external and balance of payments stability. Any changes in government revenue and consumption resulting from de-cashing will translate into changes in the level of government saving, which, for a given level of public investment and an unchanged private sector saving-investment balance, would change the current account. The direction of the shift would largely depend on whether de-cashing would improve the overall fiscal balance or lead to its deterioration. The outcome depends on its relative impact on specific revenue and expenditure lines, primarily those shown in red (Figure 4). 


\begin{tabular}{|c|c|c|c|}
\hline \multicolumn{4}{|c|}{ Figure 4. Fiscal Effects of De-Cashing } \\
\hline Revenue & Impact & Expenses & Impact \\
\hline Taxes & + & Current expenditure & \\
\hline On income, profits, and capital gains & + & Compensation of employees & - \\
\hline On payroll and workforce & + & Use of goods \& services & - \\
\hline On property & + & Subsidies & \\
\hline On goods and services & + & To public corporations & - \\
\hline General (VAT, sales, turnover) & + & To private enterprises & - \\
\hline Excise & + & Interest & + \\
\hline Profit of fiscal monopolies & + & On external debt & \\
\hline Specific services & + & On domestic debt & \\
\hline Use of goods & + & Social benefits & \\
\hline On international trade and transactions & + & Other & \\
\hline Customs and other import duties, o/w & + & Capital expenditure & \\
\hline Taxes on exports & + & Externally financed & - \\
\hline Profit of export and import monopolies & + & Domestically financed & - \\
\hline Exchange profits and taxes & + & & \\
\hline Other duties and charges & + & Fiscal balance (net lending/borrowing) & $+/-$ \\
\hline \multicolumn{4}{|l|}{ Social contributions } \\
\hline Grants & & Financing (net acquisition of financial assets & $-/+$ \\
\hline From foreign governments & + & Domestic & \\
\hline From international organizations & + & Bank & \\
\hline From other government units & & Central bank & \\
\hline Other revenue & - & Commercial banks & \\
\hline Property income (profit transfers) & - & Nonbank & \\
\hline Interest & & External & \\
\hline Sales of goods and services & & Drawing & + \\
\hline Fines, penalties & & Repayments & \\
\hline
\end{tabular}

\section{In principle, de-cashing should improve tax collection by reducing tax evasion.}

In Sweden, for example, with de-cashing the government has benefited from more efficient tax collection, because electronic transactions leave a trail. To the contrary, in countries like Greece and Italy, where cash is still heavily used, tax evasion remains a big problem. The visibility of tax payments by transfers through banks can serve as a deterrent to tax underreporting and other evasion strategies. Most developed countries and many developing countries have already implemented policies on electronic tax payments and use them as a tax control instrument. However, as these policies require taxpayers to acquire and install electronic payment systems, compliance costs are unavoidable. Recent studies showed that while electronic payments did not appear to influence VAT collection, the negative effects of cash collection on VAT performance is unambiguous, at least in the countries where electronic cash payments are well-established (Bundesbank 2014). Finally, electronic payments may also lead to new forms of tax evasion and could incentivize barter, facilitated by improved technology, which will hamper tax collection.

38. The magnitude of possible improvements in tax collection is hard to estimate.

Given the scale of cash-based tax evasion, one has to assume a fairly modest impact on 
behavior to generate a substantial increment to tax revenues. For example, the tax evasion in the United States, called tax gap, was estimated by the IRS at US $\$ 458$ bn on average in 2008-2010 (IRS, 2016). The major components of the tax gap are the underreporting of individual income tax (US\$ 264 bn) and employment tax (US\$84 bn). If eliminating US\$100 bills meant-to take a simple assumption-that 10 percent of this gap would be collected, the additional tax contribution would be US\$ 35 bn a year. In the European Union, tax evasion is estimated at $€ 1$ trillion a year (EU, 2017). Using the same illustrative logic, the elimination of large denomination bills of the Euro and British pound would help recover $€ 100$ bn in tax arrears. In developing countries, additional tax revenue is hard to estimate, given the paucity of analysis on tax compliance gaps in general.

39. With de-cashing, governments may reduce their interest expenditure because of de-cashing due to lower interest payments to central banks. Central banks usually put currency into circulation by purchasing government bonds on the secondary market. So the purchase does not increase interest costs to the government. On the contrary, it increases the demand for bonds and thus lowers the interest rate that the government would have to pay. Governments have to pay interest to the central banks on these bonds, which represents their seingiorage and may be substantial. In the United States, for example, the FY 2017 seigniorage amounted to 0.46 per one dollar issued (US Mint, 2017), and such seigniorage payments amount to about US\$70 billion a year. In Sweden, however, seigniorage represents only 1.1 percent of the central bank's balance sheet (The Riksbank, 2015). Overall, however, it is not immediately clear that de-cashing would provide savings to the consolidated balance sheet of the public sector (ministry of finance and the central bank) because of the effects described above. These interest payments are a transfer between the central bank and the ministry of finance.

\section{De-cashing may reduce the government's non-tax revenue through lower profit}

on currency issuances. The government purchases the currency from a domestic or foreign mint (or bureau of engraving) and delivers the currency to the central bank. In the central bank's accounts, the nominal (face) value of the currency is recorded as vault cash (Currency-Domestic), along with a corresponding increase in the central bank's liability (Transferable deposits - In domestic currency) to the central government. Through this transaction, the central government obtains revenue, which is equal to the difference between the nominal value of the currency and the cost of the acquisition, distribution, and maintenance of the currency. If the nominal value of currency issued declines with decashing, so does government revenue from this operation.

41. Finally, de-cashing may lead to budgetary costs. In most cases, the country would have to introduce deep institutional and legislative reform to initiate and carry over decashing. The implementation of many electronic payment procedures is technically complex, and requires extensive training of personnel, procurement of new equipment and technology, redrafting of domestic regulation, and the corresponding institutional changes, including strengthening enforcement capacity. The specific expenditure items that can be affected by 
the need to finance these implementation costs may include spending on wages and salaries because the authorities need to hire and train additional staff, procurement of goods and services for the purchases of new equipment, and investment in rebuilding an electronic payment infrastructure. Investment can be financed domestically and externally. Some countries may receive the support of external donors for the adjustment period. In the latter case, the source of financing can be either loans, shown as a financing item in the budget, or grants included in revenue.

42. Overall, fiscal implications of de-cashing seem ambiguous. The impact on the fiscal balance and, as a result, on the saving-investment balance of the government, would largely depend on the relative impact of revenue and expenditure items affected by decashing. On the revenue side, tax revenue most likely will increase with better collection, owing to more rigorous and traceable procedures. Non-tax revenue most likely would drop with lower profit transfers from seingiorage by the central bank. On the expenditure side, interest expenditure to be paid to the central bank on government bonds would be lower. However, at the same time, additional expenditure, at least for the transition period, can be expected to finance the de-cashing process, which can increase payments for wages and salaries, goods, and services, and the procurement of capital goods. Relatively prolonged transition periods could help smooth out the negative impact, as an increase in tax collection would help offset some losses.

\section{Balance of Payments Effects}

43. The impact on de-cashing on most balance of payments flows most likely will be marginal (Figure 5). For small to medium-sized countries, de-cashing is mainly a domestic operation with little direct implications for the rest of the world. The impact on the current account should be expected mainly through the saving-investment balance, which in turn critically depends on the outcome of de-cashing for the public sector. If the fiscal balance improves as tax revenue increases outweigh non-tax revenue losses and additional transitional expenditure, the current account would improve. This outcome would mainly reflect stronger exports, as government invests part of its collected taxes, and improves infrastructure, competitiveness, and the business environment. On the other hand, in some countries de-cashing may require additional imports of equipment and technology, which may temporarily worsen the current account. 


\begin{tabular}{|c|c|c|c|}
\hline \multicolumn{4}{|c|}{ Figure 5. Balance of Payments Effects of De-Cashing } \\
\hline 1. Current account & Impact & 2. Capital account & Impa \\
\hline Goods and services & & Gross acquisitions /disposals of non-produced non-financial assets & \\
\hline Goods & & Capital transfers & + \\
\hline General merchandise & $+/-$ & & \\
\hline Net exports of goods under merchanting & & 3. Financial account & \\
\hline Non-monetary gold & & Direct investment & + \\
\hline Services & & Portfolio investment & + \\
\hline Manufacturing services & - & Financial derivatives & \\
\hline Maintenance and repair services & - & Other investment & \\
\hline Transport & $+/-$ & Other equity & \\
\hline Travel & $+/-$ & Currency and deposits & \\
\hline Construction & - & Loans & \\
\hline Insurance and pension services & - & Insurance, pension, and standardized guarantee schemes & \\
\hline Financial services & $+/-$ & Trade credit and advances & $+/-$ \\
\hline Charges for the use of intellectual property & $+/-$ & Other accounts & \\
\hline Telecommunications, computer, and information services & $+/-$ & Special Drawing Rights & \\
\hline $\begin{array}{l}\text { Other business services } \\
\text { Personal, cultural, and recreational services }\end{array}$ & - & \begin{tabular}{|l|} 
4. Reserve assets \\
\end{tabular} & \\
\hline Government goods and services & & Monetary gold & \\
\hline Primary income & & Special Drawing Rights & \\
\hline Compensation of employees & - & Reserve position in the IMF & \\
\hline Investment income & - & Other reserve assets & $+/-$ \\
\hline Other primary income & & & \\
\hline Secondary income & & & \\
\hline General government & & & \\
\hline $\begin{array}{l}\text { Financial corporations, non-financial corporations, households } \\
\text { Adjustment for change in pension entitlements }\end{array}$ & + & & \\
\hline
\end{tabular}

44. The balance on the primary and secondary income accounts would be affected mainly through income transfers. If de-cashing is based on the distributed ledger-like technology, such as the Bitcoin, it can dramatically reduce the cost of international transfers, especially remittances intermediated by correspondent banks. Through correspondent banking relationships - agreements between banks to provide payment services to each other-banks can access financial services in different jurisdictions and provide cross-border payment services to their customers. The costs of sending international remittances, however, are notoriously high, at about 8 percent of the amount sent. In contrast, the cost with electronic money, such as Bitcoin, is estimated to be about 1 percent (Goldman Sachs, 2014). A blockchain based remittance system has already emerged in some economies. For instance, in the Philippines and Kenya, blockchain based intermediaries offer money transfer services via Bitcoin and subsequent conversion of Bitcoins back into fiat currency for withdrawal by recipients through either their mobile phones or a bank account (IMF 2016).

\section{Finally, de-cashing may reduce a very profitable impact on the balance of} payments of certain countries from the international circulation of their national currency. While the cost of printing banknotes is minimal, foreign economic agents must provide goods and services at the face value of the banknote to obtain it. Primarily, this flow is important for the United States and the Eurozone. "What is true is that the large holdings of U.S. currency outside the United States-largely in the form of \$100 bills, held for obvious reasons - represent, in effect, a roughly $\$ 500$ billion zero-interest loan to America. That's nice, but even in normal times it's only worth around \$20 billion a year, or roughly 0.15 percent of GDP" (Krugman, 2013). 


\section{E. Structural Effects}

46. De-cashing may lead to increased financial inclusiveness. By construction, a shift from currency to transferrable deposits would require people to have at least debit accounts with banks. Small businesses that would accept bank money would increase their profits, as most people would have easily accessible and reliable means of payments in the form at least of debit cards and, potentially, tele-payments.

47. De-cashing should help reduce illegal migration. With less currency in circulation, employers that attract illegal immigration by cash payment would have fewer options to pay for their services off the books.

48. De-cashing can help improve the environment. Paper money has been the currency of choice for centuries with clearly negative implications for forestry. Now, it is being replaced with polymer notes, which are already used in over 20 countries. A polymer bill leads to a 32 percent reduction in global warming potential and a 30 percent reduction in primary energy demand compared with paper (Wang, 2016). However, from the environmental standpoint, transferrable deposits would outperform both paper and polymer currencies, as they do not need to be neither produced nor disposed.

49. However, social implications of de-cashing can be substantial. Carrying cash is a human right and is written into constitutions, which therefore have to be changed. Social conventions may also be disrupted as de-cashing may be viewed as a violation of fundamental rights, including freedom of contract and freedom of ownership. While convertible deposits cannot be stolen in a conventional robbery, they can be hacked. There are, obviously, concerns as the cases of electronic fraud have more than doubled in the past decade.

50. De-cashing would remove a tacit means of social support. In many developing societies, the government implicitly encourages small unregistered entrepreneurship, which relies entirely on cash transactions with no or little formal accounting. By forgoing tax revenue, the authorities allow small businesses to create informal mechanisms of social selfsupport, which the government simply cannot afford to finance through formal social payments. At the same time, microfinance most likely will be more difficult as it still relies largely on cash contributions.

51. Finally, currency substitution can become quite possible. If there is not enough domestic currency because of the unmeasured pace of de-cashing, foreign currencies or surrogate currencies may start to be used for murky transactions. 


\section{Conclusions And Policy Options}

52. De-cashing by a shift towards transferrable deposits reflects a natural drive towards economic flexibility and growth. It should be seen as a long-term project and does not suggest an immediate move a cashless society. Although some countries most likely will de-cash in a few years, going completely cashless should be phased in steps. The de-cashing process could build on the initial and largely uncontested steps, such as the phasing out of large denomination bills, the placement of ceilings on cash transactions, and the reporting of cash moves across the borders. Further steps could include creating economic incentives to reduce the use of cash in transactions, simplifying the opening and use of transferrable deposits, and further computerizing the financial system.

53. The private sector led de-cashing seems preferable to the public sector led decashing. The former seems almost entirely benign (e.g., more use of mobile phones to pay for coffee), but still needs policy adaptation. The latter seems more questionable, and people may have valid objections to it. De-cashing of either kind leaves both individuals and states more vulnerable to disruptions, ranging from power outages to hacks to cyberwarfare. In any case, the tempting attempts to impose de-cashing by a decree should be avoided, given the popular personal attachment to cash. A targeted outreach program is needed to alleviate suspicions related to de-cashing; in particular, that by de-cashing the authorities are trying to control all aspects of peoples' lives, including their use of money, or push personal savings into banks. The de-cashing process would acquire more traction if it were based on individual consumer choice and cost-benefits considerations.

\section{The macroeconomic impact of de-cashing would depend on the balance of its} costs and benefits, but most likely will still be positive on a net basis. On the side of the benefits, de-cashing should raise recorded GDP growth by reducing transaction costs, creating incentive for the informal economy to join the formal sector, and simplifying transactions, in particular in the private sector, services, and consumption. De-cashing would also expand revenue collection by expanding the taxable base, curbing tax evasion and fraud, and reducing interest payments on government debt. De-cashing should improve the transmission mechanism of monetary policy. With most money having the form of transferrable deposits, central banks would be able to influence liquidity conditions and credits better with their interest rate policy. As de-cashing gives incentives to economies' agents to convert their currency in bank deposits, the deposit base of the banking system will increase, which can help reduce the lending rates and expand credit. In particular, if the negative interest rate policy becomes a mainstream policy option, de-cashing would be critical for its efficiency. On the external side, de-cashing can improve the current account, mainly through its impact on the saving-investment balance of the government sector and on remittances and other income flows, which should increase with lower transaction costs. Finally, in the structural area, de-cashing can help improve financial inclusiveness with easier digital access to banking services. The labor market would be more orderly, as fewer illegal immigrants would be attracted by cash payments. The central banks will cut their costs with 
no need to produce and destroy either paper or plastic currency.

55. On the side of the costs, de-cashing may create temporary frictions in all sectors as the well-established cash procedures have to contract. In the private sector, there may be disruptions from de-cashing, as a substantial part of consumption transactions and private investments, in particular in housing, is made in cash. Also, households and small private businesses may see carrying cash and conducting anonymous transactions as their constitutional right. Their discontent can lead to social tensions, strikes, and, therefore, GDP losses. For the fiscal sector, de-cashing may represent a substantial financial burden, as additional capital and current expenditure will have to be made to procure equipment to manage cashless settlements. Additional spending will be needed for the training of personnel on cashless transaction, although part of these costs would be borne by the private sector. Losses in profit transfers are also possible. In the monetary sector, de-cashing may reduce central bank independence with the lost seingiorage revenue. De-cashing would also deprive central banks of a useful tool in the form of changes in the demand for cash, which has served as a leading indicator of a possible financial crisis. It is not immediately obvious that de-cashing would help improve financial inclusiveness. If the poorest cannot have access to computers or mobile phones, they will lose the most important financial asset that they rely on to save: cash. In the external sector, some deterioration of the current account may be expected, at least on a temporary basis, as the de-cashing country has to import the massive equipment needed to service cashless transactions and outsource the de-cashing services (programming, training, etc.) to non-residents. Finally, in the structural area, substantial groups of the population not yet familiar with digital payments may feel disadvantaged, which may lead to social strain. Also, the tacit form of social protection used in many developing countries in the forms of forgone tax payments would be largely eliminated and has to be replaced with more direct forms of social protections. Finally, if cash is still an important means of payment in a de-cashing country, currency substitution may become an issue, as economic agents would be forced to use other currencies as a means of payment.

\section{Coordinated efforts on de-cashing could help enhance its positive effects and} reduce potential costs. At least at the level of major countries and their currencies, the authorities could coordinate their de-cashing efforts. Such coordinated efforts are, in particular, important in the decisions to phase out large denomination bills for all major currencies, to use ceilings and other restrictions on cash transactions, and to introduce the reporting requirements for cash transactions or their taxation. For currency areas, a single decashing policy would be clearly preferable to a national one. Finally, consensus between the public and the private sector and outreach on the advantages and modalities of gradual decashing should be viewed as key preconditions for its success. 


\section{REFERENCES}

Agarwal, R. and M. Kimball, 2015, "Breaking Through the Zero Lower Bound," IMF Working Paper 15/224 (Washington: International Monetary Fund).

Aloni Y., 2014, “Israel Eyes Becoming a Cashless Society. Israel Today,” May 26, http://www.israeltoday.co.il/NewsItem/tabid/178/nid/24635/Default.aspx.

Deutsche Bundesbank, 2014, "The Usage, Costs and Benefits of Cash-Revisited." Availabel at www.bundesbank.de.

—_, 2016, "Cash Symposium 2016.” Available at https://www.bundesbank.de/Redaktion/EN/Topics/2016/2016_06_15_bargeldsympos ium.html.

Euromonitor International, 2016. Available at http://www.euromonitor.com/usa.

European Commission, 2017, “A Huge Problem.” Available at http://ec.europa.eu/taxation_customs/fight-against-tax-fraud-tax-evasion/a-hugeproblem en.

Henley, Jon, 2016, "Sweden Leads the Race to Become Cashless Society," Observer. Available at https://www.theguardian.com/business/2016/jun/04/sweden-cashlesssociety-cards-phone-apps-leading-europe.

International Monetary Fund, 2016, "Virtual Currencies and Beyond: Initial Considerations," IMF Staff Discussion Note 16/03. Available at http://www.imf.org/external/pubs/cat/longres.aspx?sk=43618.

—, 2016, Monetary and Financial Statistics Manual (MFSM) (Washington). Available at https://www.imf.org/external/pubs/ft/mfs/manual/.

Institute for New Economic Thinking, https://www.ineteconomics.org/ideaspapers/blog/monetary-finance-mechanics-complications.

Internal Revenue Service (IRS), 2016, Tax Gap Estimates for Tax Years 2008-2010. Available at https://www.irs.gov/uac/the-tax-gap.

Krugman P. (2013). Godwin and the Greenback, http://krugman.blogs.nytimes.com/2013/10/22/godwin-and-the-greenback.

Plassaras, N. A., 2013, "Regulating Digital Currencies: Bringing Bitcoin Within the Reach of IMF," Chicago Journal of International Law, 14, 377.

Riksbank, 2015, Annual Report. Available at http://www.riksbank.se/en/Press-andpublished/Published-from-the-Riksbank/Annual-Report. 
Rogoff, K. S., 2014, “Costs and Benefits to Phasing Out Paper Currency,” No. w20126, National Bureau of Economic Research.

Rogoff, K. S., 2014, Costs and Benefits to Phasing Out Paper Currency (Unpublished memo).

Sands P., 2016, "Making it Harder for the Bad Guys: The Case for Eliminating High Denomination Notes," M-RCBG Associate Working Paper No. 52. Available at https://www.hks.harvard.edu/centers/mrcbg/publications/awp/awp52.

Summers L., 2016, It's Time to Kill the $\$ 100$ bill," Washington Post, February 16. Available at https://www.washingtonpost.com/news/wonk/wp/2016/02/16/its-time-to-kill-the100-bill/?utm term=.b089e11452f7.

System of National Accounts, 2008, United Nations. Available at http://unstats.un.org/unsd/nationalaccount/sna2008.asp.

The Nature and Necessity of a Paper-Currency, A Modest Enquiry into the Nature and Necessity of a Paper-Currency. Philadelphia: Printed and Sold at the New PrintingOffice, near the Market. 1729.6 (Historical Society of Pennsylvania) http://founders.archives.gov/documents/Franklin/01-01-02-0041.

The Shift to a Cashless Society is Snowballing. Available at http://www.visualcapitalist.com/shift-cashless-society-snowballing/.

Turner A., 2013, "The Case for Monetary Finance-An Essentially Political Issue.”

U.S. Mint FY 2017, President's Budget February 9, 2016. Available at https://www.treasury.gov/about/budget.

Wang, Ping. ,2016, “The Future is Plastic,” Finance and Development, International Monetary Fund, June, Vol. 53, No. 2. Available at http://www.imf.org/external/pubs/ft/fandd/2016/06/currency.htm. 